\title{
“We Get you to your doorstep!'” An Innovative Strategy for Garuda Airlines?
}

\author{
Ameen Ali Talib ${ }^{1, *}$ \\ ${ }^{1}$ Head, Applied Projects, School of Business, Singapore University of Social Sciences, Singapore \\ *Correspondence: Head, Applied Projects, School of Business, Singapore University of Social Sciences, Singapore. \\ E-mail: ameentalib@suss.edu.sg
}

Received: June 5, $2018 \quad$ Accepted: July 11, $2018 \quad$ Online Published: July 23, 2018

doi:10.5430/mos.v5n3p1

URL: https://doi.org/10.5430/mos.v5n3p1

\begin{abstract}
Innovation is the process of developing, creating and implementing new technologies, products and services that result in added value. Garuda Indonesia Airlines is a company that can innovate its' products/services.

This paper looks at Garuda Airlines and proposes a strategy involving innovation of product to increase the airline load factor and regain market share. The proposed strategy is also congruent with the company vision.
\end{abstract}

Keywords: strategy, innovation, garuda

\section{Introduction}

Innovation can be defined as the process of developing, creating and implementing new technologies, products and services that result in added value (Kennard 2016). Strategies implemented should have innovation and must be congruent with the vision.

Garuda Indonesia is the national airline of Indonesia. The carrier operates an extensive domestic, regional and international network of services throughout Asia, Australia, Europe and the Middle East. In 1982, Garuda was the $2^{\text {nd }}$ best airline in Asia. This was mainly due to the monopoly they had in Indonesia's aviation industry (Ardiansyah 2017). However, since the Indonesian government issued decree no 11/2011 deregulating air transport, Garuda no longer dominates the domestic aviation services in Indonesia. In 2007 Garuda experienced a ban on flights to European Union but In Jun-2010, Garuda resumed services to Europe after an extended EU imposed ban. Garuda suffered in that period as their reputation was harmed and Lion Air took advantage of this with an expansion plan to capture the majority domestic market share.

Garuda had recently undergone a thorough restructuring in what it labelled "The Quantum Leap", which involved a dramatic redesign of the airline's strategic direction, network, brand and fleet. Garuda earned the prestigious 5 star rating from SkyTrax in 2014 marking the end of the Quantum Leap program. Garuda then appointed Wibowo as CEO. He was Citilink CEO prior to that. Wibowo started a 'Quick Win' cost cutting drive.

In line with the airline's efforts to develop and strengthen its network, especially in the domestic market, it launched a new sub-brand "Explore" along with the introduction of the ATR 72-600 aircraft into the fleet. In addition to the sub-brand "Explore", Garuda Indonesia also introduced the brand "Explore Jet" to operate its Bombardier CRJ1000 NextGen fleet, serving the airline's network in both eastern and western Indonesia.

The company vision statement reads "to be a sustainable airline company through customer-oriented services and growth in profits".

In 2016 Garuda Airlines has increased its capacity resulting in increase in total revenue but a drop in profits due to a decreased load factor. Therefore, strategies are required to increase the load factor.

\section{Methodology: The Current Situation analysis}

For most of modern Indonesian history, Garuda Indonesia has dominated the Indonesian air travel market share. 
However, started in 2000, Lion Air started to grow and become a serious rival in domestic air travel in Indonesia. By Mid-2015, Lion Air rules Indonesia's domestic air travel market share by 41.6 percent, while Garuda Indonesia came in second with 23.5 percent share. Sriwijaya Air came in third with a market share of 10.4 percent, followed by Garuda's low-cost subsidiary Citilink (8.9 percent) and Lion Air's regional flight service Wings Air (4.7 percent). Indonesia AirAsia, a unit of the Malaysian budget airline, had a 4.4 percent market share. Overall, Indonesian domestic air travel business is overwhelmingly ruled by two groups; Lion Air group and Garuda Indonesia group.

Garuda Indonesia's full-year 2016 net profit dropped 88\% to $\$ 9.4$ million, compared to \$78 million in 2015 . Operating revenue for the year was up 1.3\%, although the capacity gain of $13.3 \%$ outstripped the traffic increase of $8.3 \%$. Load factor fell 3.4 points to $73.8 \%$. Passenger yield dropped $7.1 \%$ in 2016 . Unit costs fell $7 \%$, and were down $1.5 \%$ excluding fuel. Average fuel price declined $17.3 \%$. Garuda increased its cargo volume by more than $18 \%$ in 2016, with revenue up 16.7\%. (Garuda Annual report 2016)

The Company posted $13.26 \%$ growth in production capacity (Availability Seat Kilometre/ASK) in 2016. With such ASK achievement, the Company managed to register a positive climb of $8.30 \%$ in Revenue Passenger Kilometres (RPK) in 2016. In other words, the passenger traffic indicated an upward trend while on the other hand, the fiercer competition also caused the average ticket price to drop, which was among the biggest challenges for the Company in 2016. The average ticket price dwindled in conjunction with the declining passenger yield by $7.10 \%$. Meanwhile, average passenger load factor (seat load factor) in 2016 fell compared to the same period in the previous year to $73.83 \%$ from $77.21 \%$ in 2015. On-Time Performance (OTP) in 2016 reached $89.51 \%$, compared to the previous year at $87.99 \%$.

Garuda Indonesia has set "Sky Beyond" as the Company's Long-Term Plan for the period of 2016 -2020. In line with that, the performance of Garuda Indonesia in 2016 was particularly focused on the attempt of consolidation which aim for a better operational margin and to ensure the standardization of service. In its implementation, "Sky Beyond" encompasses three main strategies: Excellent Indonesian Hospitality, Return Maximization, and Group Synergy.

Operational performance-wise, the Company could not meet the target of number of passengers in 2016 owing to the increasingly intense competition in both domestic and international airline markets as well as lethargic passenger growth within the weak financial settings. Such backdrop also led to the Company to fall short of its targets in production capacity (ASK), demand (RPK), seat load (SLF) and number of carried passengers. The target shortfall in terms of number of carried passengers also led to the Company's market share shrinking.

\subsection{SWOT Analysis}

To be competitive it is crucial to determine weakness, strengths, opportunities and threats. This is also necessary to design a strategic plan. We can apply Porter's five forces analysis and/or do a SWOT analysis followed by TOW analysis as we did below.

\begin{tabular}{ll}
\hline External & Internal \\
\hline Threats & Weaknesses
\end{tabular}

1. Open sky policy resulting in intense competition.

2. Increased capacity and routes of low cost carriers.

3. Cheaper surface transport and current construction of toll roads.

\section{Fuel prices increase *}

5. Excessive competition with regards to pricing and possible 'price war' affecting load factor/yields.

6. Natural disasters such as Bali volcano eruption leading to closure of airports.

7. high capital requirements
1. Lack of big carrier aircrafts

2. Jakarta as International hub not conveniently located except for EuropeAustralia route.

3. National carrier with government influence.

4. Current losses and potential difficulty in raising funds 
1. New fleet

2. Indonesia economic growth

3. Increase in international and domestic travel

4. Surface transport cannot be total substitute for air travel as Indonesia is made up of islands.

5. Large Indonesian Migrant workers (TKI)

6. Tourism to Indonesia is not city based as many tourists go inland to visit Volcano Mountains.

7. Increase in domestic travel market and large population

8. Current low fuel costs

9. Huge number of haj and Umrah passengers from Indonesia
1. National carrier with government backing

2. Increase in flight network joining SkyTeam and other code sharing

3. Focus on cargo.

4. Adopting technology and being innovative.

5. Good domestic network

*The current political landscape in Middle East is in turmoil. USA has recently moved their embassy in Israel to Jerusalem, the Gulf crisis between Qatar and Saudi Arabia has no signs of near solution, Yemen conflict is escalating and the tension between Saudi Arabia and Iran is escalating. The local political situation in Saudi Arabia is also volatile after the recent 'house of Saud' internal conflicts. If these issues escalate further there is a possibility of Brent crude prices going up.

\subsection{TOW Analysis}

TOWS matrix identifies the factors that will affect the existing potentials factor at company bot good and bad factors. These factors will be anticipated as a strategy to develop the company (Ardiansyah 2017). As shown in the table below, strength is what Garuda does well and weakness is what it doe not do well. Opportunities are external conditions that support strength and threats are external conditions that are not necessarily related to strength or weakness.

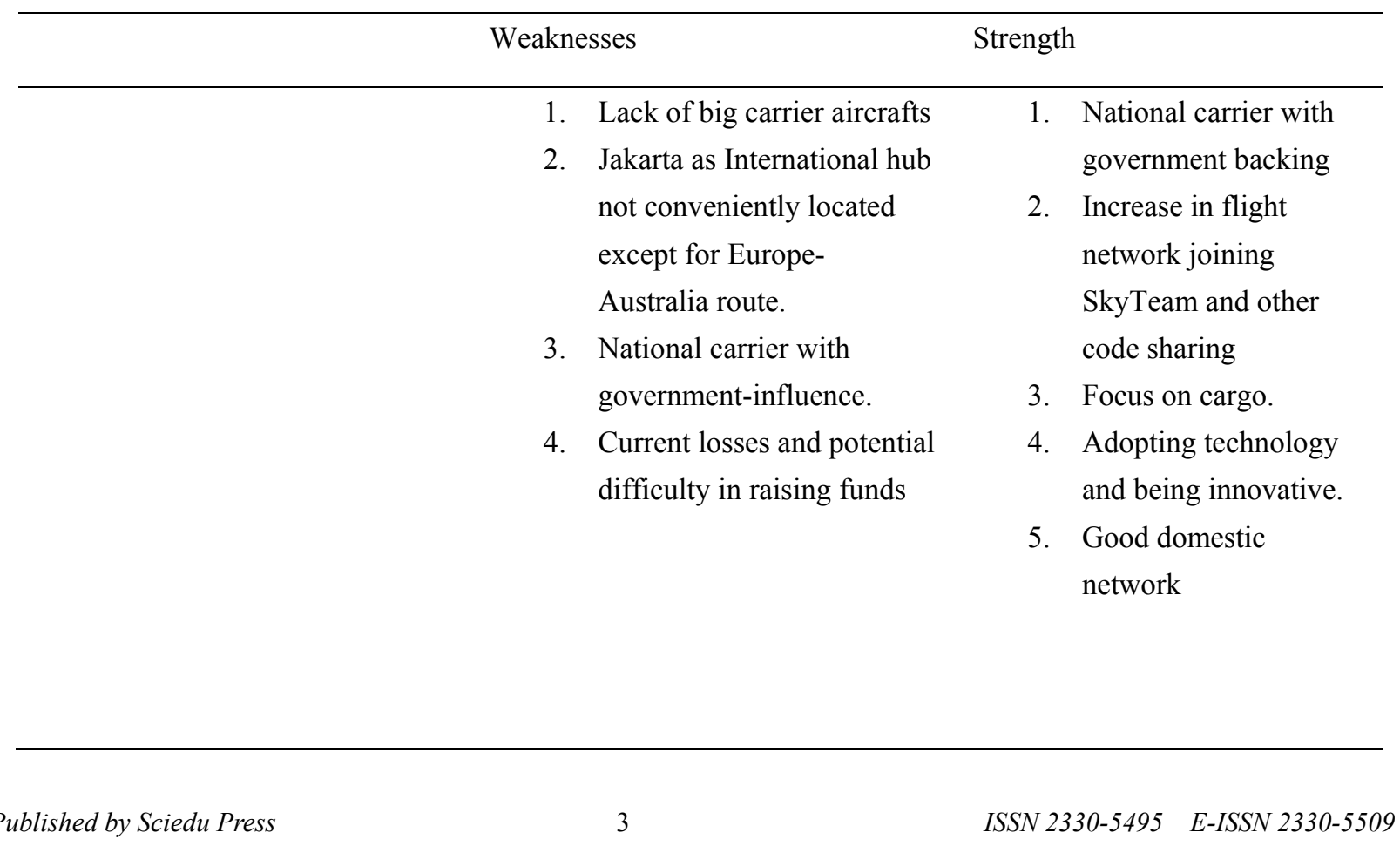




\begin{aligned} & \hline Opportunities \\ & \hline 1. New fleet \\ & 2. Indonesia economic \\ & growth \\ & 3. Increase in international \\ & and domestic travel \\ & 4. Surface transport cannot \\ & be total substitute for air travel as Indonesia is \\ & made up of islands. \\ & 5. Large Indonesian \\ & Migrant workers (TKI) \\ & 6. Tourism to Indonesia is \\ & not city based as many \\ & tourists go inland to visit \\ & volcano mountains. \\ & 7. \\ & Increase in domestic \\ & travel market and large \\ & population \\ & 8. $\begin{array}{l}\text { Current low fuel costs } \\ \text { 9. }\end{array} \\ &$ large haj and Umrah \\ & passengers from \\ & Indonesia \end{aligned}

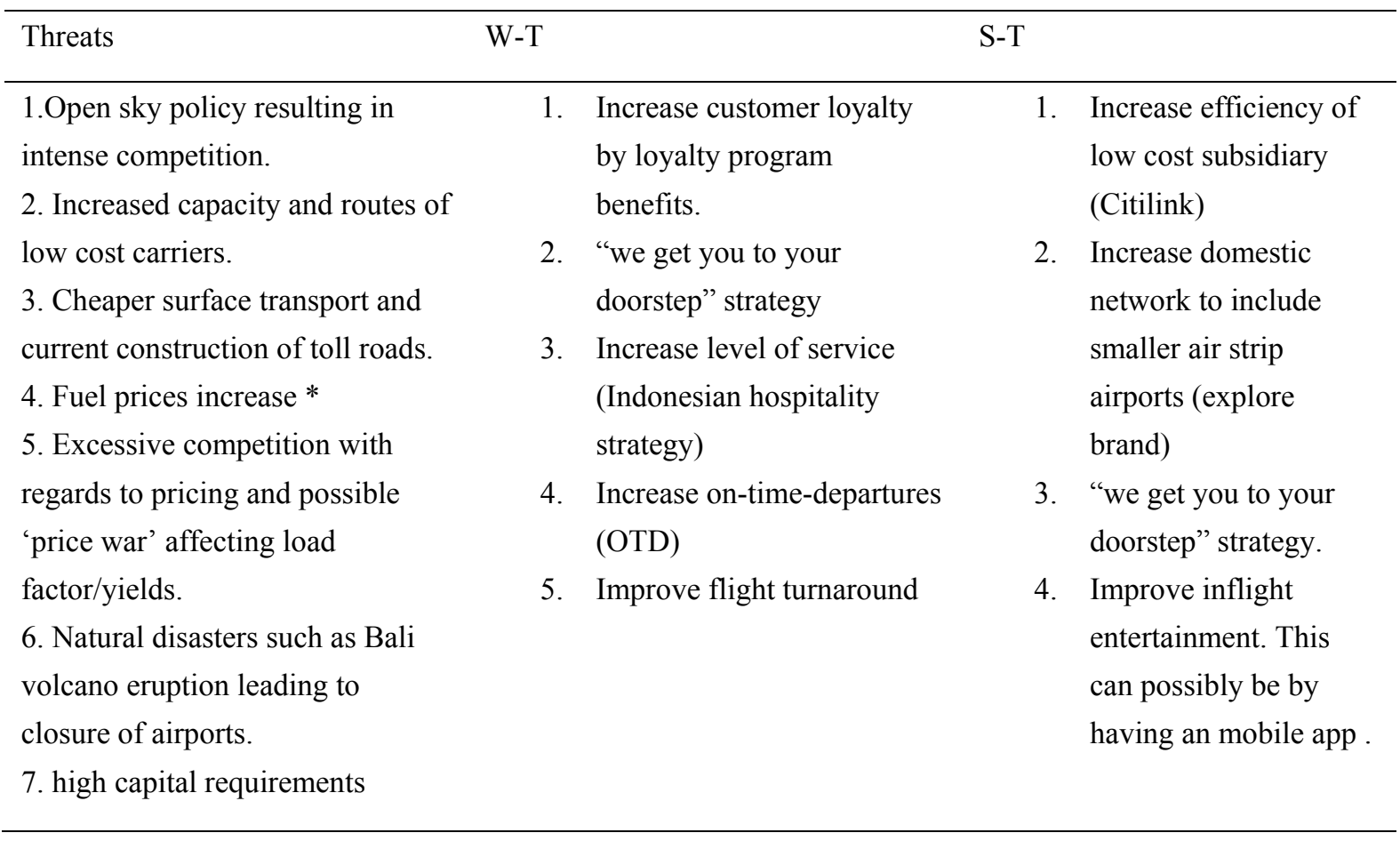




\subsection{PESTLE Analysis}

It is important to understand the environment the business is operating in so that the right strategies can be implemented.

POLITICAL ECONOMICAL

1. Garuda enjoys strong backing from Government.
1. Indonesia large population and its

Landscape provide growing market.

2. GDP and air travel growth in Indonesia favours Garuda

3. Tourism in Indonesia expected to increase

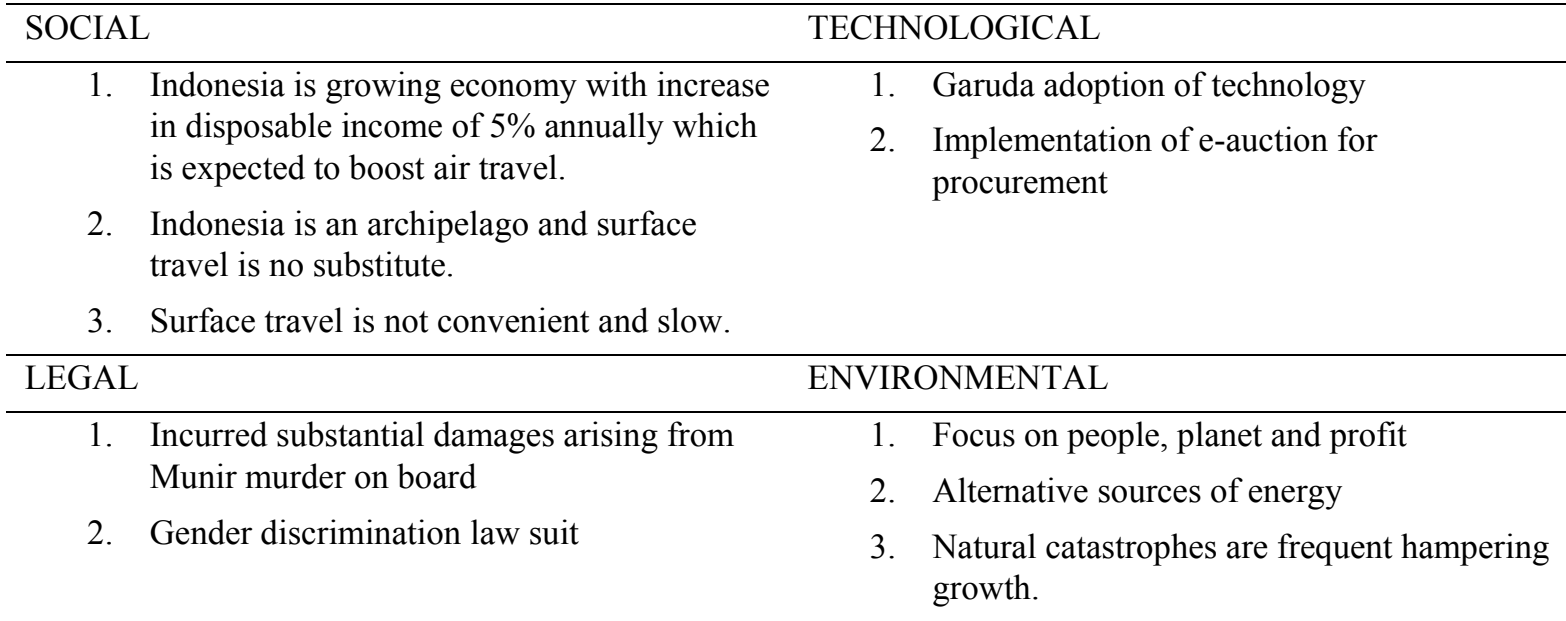

\subsection{Market Segments}

This paper focuses only on passenger and not cargo (but recognizes the importance of cargo business). The passenger market can be divided into 4 main categories

1. International flights (long haul)

2. Regional Flights/ short haul

3. Domestic flights

4. Haj and Umrah

\subsubsection{International Flights}

The difficulty with the long haul flights is the need for big carriers. Garuda advertises over 70 international destinations using code sharing arrangements. That is a strategy to continue implementing for the meantime; this is particularly since long-haul are not as profitable as regional. Coordinating Maritime Affairs Minister Rizal Ramli in 2015 had blocked Garuda's purchase of Airbus A350 as he felt that Garuda's routes to Europe only had a 30 percent passenger load factor. Instead of expanding its international routes, it would be better if Garuda focused on domineering the domestic and regional markets(Note 2).

The flight to Europe are important for Garuda reputation and pride after the EU ban on Indonesian air carriers.

\subsubsection{Regional Markets And Domestic Markets}

"We can rule the regional market in five to seven years. When we are strong enough, then we can go onto the next step. The President has agreed to the cancellation of the purchase of the Airbus A350 and we will summon the [Garuda] management to change its plans," Rizal. (http:/www.thejakartapost.com/news/2015/08/13/rizal-ramli-urges-Garuda-cancel-airbus-a350-purchase-plan.html)

This paper recommended strategy is expansion of regional market. The Regional expansion is to be implemented by the domestic market expansion. 
There are a number of aspects that will help accelerating the growth of airline business in Indonesia. Among them are the increased number of passengers, economic growth, population, and geographical locations. In terms of population, Indonesia has 250 million population while total passenger traffic only reaches 100 million. As such, there is such an ample room to grow. In addition, Indonesia's economy is among the countries with the strongest growth than the rest of the world. Geographically speaking, Indonesia as an archipelago country, unquestionably favours air transportation. Those are the key aspects that will propel growth of national airline industry. Some government initiatives that also support the growth of Indonesia's airline include infrastructure improvement by enhancing quality of older airports and construction of new airports will still be the catalyst for the airline business in Indonesia.

Air-travel market share in Indonesia will continue to grow at the expense of surface travel as most air travel in domestic market in Indonesia is over water. Surface travel currently also has the added problem of lack of toll ways and constant jams where journeys take a long time vis-a-vis the distance. This is particularly so during festive seasons. Indonesia currently undergoing building toll ways connecting Jakarta with rest of Java; surface travel will recapture some market when the toll ways are completed.

Garuda expects its capacity to rise to $10.00 \%-15.00 \%$ in 2017 in which domestic growth will focus on capacity expansion in Eastern Indonesia (and has launched explorer brand to enter the smaller airport destinations(Note 2) and Citilink low-cost lights. Domestic market indicates a relatively higher growth than international market. Historically, domestic market grow by CAGR 2011-2015 at 6.30\% and the growth is likely to continue into 2016-2017 at 6.90\%. As for international flights, the Company will focus on markets with bigger potentials such as China and Middle East.

\subsubsection{Domestic Market Shares}

Overall, Indonesian domestic air travel business is overwhelmingly ruled by two groups; Lion Air group and Garuda Indonesia group.

In line with the airline's efforts to develop and strengthen its network, especially in the domestic market, it launched a new sub-brand "Explore" along with the introduction of the ATR 72-600 aircraft into the fleet. In addition to the sub-brand "Explore", Garuda Indonesia also introduced the brand "Explore Jet" to operate its Bombardier CRJ1000 NextGen fleet, serving the airline's network in both eastern and western Indonesia.

Indonesia currently has 61 scheduled and unscheduled commercial airlines. The country is ranked as having the second-fastest growing aviation industry in the world after China in terms of aircraft order and business value. Domestic air passenger volumes have posted double-digit growth in the last five years. In 2013, air passenger growth reached $22.3 \%$. A year later, the figure grew by $16.7 \%$. In 2015 , Indonesian air passengers recorded a $13.1 \%$ increase. Meanwhile, international air passenger volumes grew by around 8\% in 2015 as more local and foreign carriers offer international flights.

The biggest airline in Indonesia in terms of the number of domestic passengers is Lion Air., the budget carrier has been an airline of choice among low and middle income passengers. The airline has dramatically reduced the country's standard airfare which has enabled millions of people to fly. The emergence of Lion Air has created a new base of customers for the aviation industry.

\section{The Recommendations.}

\subsection{What is the relation between Regional and Domestic market and why Garuda need recapture Domestic Market?}

Ever since the Indonesian government deregulated the aviation industry, Indonesia's aviation sector has been growing at a brisk pace in terms of passengers, airlines, fleets, flights, and airports. For example, the number of airline passengers has increased from 9 million in 1990 to around 90 million in 2016. The same goes for the country's airline fleets which have soared in numbers by more than ten-fold from 102 aeroplanes in 1990 to 1,030 in 2017.

If we look at regional travel passenger we can roughly divide them into the following 4 categories:

\section{Business Traveller}

The business traveller is taken care by Garuda under the current strategy and Garuda is competing with the likes of SIA and Thai Airways and Silk Air. Our recommend strategy does not deal with this segment as current adopted strategy does focus on them. Garuda targets the middle to high end customers currently.

II. Tourists / leisure

This is probably the biggest regional customers segment. There are the standard tourist destinations such as Bali, Jakarta, Bandung, Jogja etc. which are currently well served by regional airlines. 
Garuda had a reputation from the past that flights to destinations other than Bali and Jakarta had to go via Jakarta. In recent times Garuda has increased its direct flights from other airports to regional airports. The main competitor would be Jetstar, Air Asia and Lion Air Group. The tourist traveller would opt for cheaper fares especially on short flights.

Garuda could have its Citilink brand fly some of these routes for cheaper fares. Garuda brand can sell fares at higher rates with added value.

A significant part of tourist travel to Indonesia is visiting volcanoes which means tourists final destinations are not the airport city, for example those visiting Bromo Mountains would fly to Surabaya and find their ways by surface travel to Bromo (a 3-hour drive).

These travellers provide opportunity to Garuda similar to the migrant workers (TKIs). Garuda can offer a service to get you to the final destination. Surface transport can be provided from the airport to your final destination. Touristic destinations such as Bromo is easier as a large number of people on the Surabaya flight are going Bromo.

Travellers to Bawean can connect with Airfast flight from Surabaya to Bawean. So, Garuda need to make code sharing arrangement with local carriers that fly to airports Garuda does not. They also need have arrangements with transport companies for land transport or use their transport subsidiary. Passengers can then buy airline tickets with transport to final destination.

III. Indonesian students regionally

There are a huge number of Indonesian students in Singapore and Malaysia. The opportunity that student travellers offer are unique in that very early confirmation of travel dates are possible. Most students go home during vacation and term dates are known well in advance.

In line with our strategy of expanding regional market share, one method is to offer discounted prices for students who book early. One possible mechanism that need be studied is offering the students a 'travel pass' allowing them to travel a number of times a year. It can even be to any destination in Indonesia. The pass can be sold for a fixed price for one year validity with maximum number of flights. This could be interesting for students as they tend to travel a known number of times a year.

\section{TKI (Tenaga Kerja Indonesia)- Indonesia migrant workers}

This is a very interesting market segment that provides opportunities. In Singapore there are over 200,000 Indonesian migrant workers and over a million in Malaysia. On average they would travel back to home once in 2 years. They tend to live in the small towns/villages within 5 hours radius of major airports. This group of travellers would appreciate a ground transport to their town.

The slogan could then be we get you to your doorstep.

This strategy focus on growing regional market through growing domestic market share and network.

\section{Haj and Umrah}

The strategic measures implemented in 2016, among others, by carrying out organizational changes in the Parent Company and SBU under Garuda Indonesia Group. To increase the utilization of potential revenue from Umrah, Hajj, and the charter, thus in February 2016 the Strategic Business Unit (SBU) of Charter, Umrah \& Hajj (JKTDU) has been established. Each year Garuda Indonesia earned substantial profits from the Indonesian pilgrimage to Middle east (Ardiansyah 2017 p6).

Currently many of the haj and umrah travellers from Indonesia go to Saudi Arabia via Malaysia; especially Aceh travellers. Haji has high traffic from Indonesia. One issue is that it is for short time period once a year. This means it requires large carriers for that period which might have no or low utilisation for rest of year. This can be overcome by chartering large carriers. Garuda need study the costing and feasibility.

Umrah is more throughout the year and constant traffic. Garuda need to liase with the umrah travel agent to divert those travelling from Malaysia to fly Garuda. One of the main competitors are Air Asia and Saudi Airlines. Garuda might consider having flights to Jeddah from Surabaya and Aceh. 


\section{Concluding Remarks}

Garuda Indonesia uses the horizontal integration by establishing Citilink which aims to reach consumers who are looking for low cost flights. Services which provided by Citilink is also comparable to premium services provided Garuda Indonesia. Garuda Indonesia using this strategy in order to compete with the power of Lion Air which has dominated the Low Cost Carrier market and domestic. This strategy has been enhanced by the explore brand.

The strategies adopted need to align to the strategic goals and vision of the business. The goal of increasing load factor is aligned with the vision of sustainability and profitability, and our proposed strategy of "we get you to your doorstep" achieves that and is congruent with the vision of attaining sustainability and profitability through customer oriented services.

Garuda need to increase its domestic and regional market share. We recommend the "we get you to your doorstep" strategy to offer the added value and have the competitive edge. This recommended strategy is enhanced by the introduction of the explore brand. The costing and feasibility of bundling the air and ground travel need to be studied and analysed.

This paper sheds light on possible strategies Garuda can adopt. The analyses in this paper is based on publicly available information as we do not have access to Garuda's management. Our main recommendation of getting you to your doorstep is an example of how strategy thinking should be aligned to the vision and be innovative and building on strengths and opportunities. This paper can be useful for strategy students and practitioners

\section{References}

Ardiansyah, S. Rendy. (2017). Management Innovation Strategy to face the competition of domestic commercial flight business in Indonesia Case study: Garuda Indonesia Airline", Proceedings of $56^{\text {th }}$ IASTEM International; Conference, New York USA 15-16 $6^{\text {th }}$ June 2017.

Grauda Indonesia Airlines Annual Report 2016.

Kennard M. (2016). The A to $Z$ of Innovation Management: the essential guide to 26 Key Innovation Management Theories, Models and Frameworks.

Ministry of Transportation Republic of Indonesia (20111) Ministrerial decree no 11/2011.

\section{Notes}

Note 1.

http://www.thejakartapost.com/news/2015/08/13/rizal-ramli-urges-Garuda-cancel-airbus-a350-purchase-plan.html

Note 2. For example currently Bawaean in East java is only served by Airfast ailines 